\title{
A survey of awareness of Pap smear and cervical cancer vaccine among women at tertiary care centre in Eastern Uttar Pradesh India
}

\author{
Anjali Rani*, Kalpana Singh, Shreya Thapa
}

Department of Obstetrics \& Gynaecology, IMS BHU, Varanasi, Uttar Pradesh, India

Received: 09 February 2015

Revised: 16 February 2015

Accepted: 01 March 2015

\section{*Correspondence:}

Dr. Anjali Rani,

E-mail: anjaliraniimsbhu@gmail.com

Copyright: ( $)$ the author(s), publisher and licensee Medip Academy. This is an open-access article distributed under the terms of the Creative Commons Attribution Non-Commercial License, which permits unrestricted non-commercial use, distribution, and reproduction in any medium, provided the original work is properly cited.

\begin{abstract}
Background: Cervical cancer is very common in developing countries. In Uttar Pradesh the literacy rate of women is low as compared to other states of India. Poverty is very high. Most women report with advance stage of cervical cancer. It can be prevented by early screening with Pap smear. Aim of our study is to know about the awareness of Pap smear and cervical cancer vaccine among women attending a tertiary hospital in Eastern part of Uttar Pradesh India.

Methods: A questionnaire based study is done on 1500 patients attending the OPD and admitted in ward over a period of one year.

Results: To our surprise only $12.06 \%$ women were aware of Pap screening test. Only $6.13 \%$ women were aware of cervical cancer vaccine. The awareness about both Pap test and cervical cancer vaccine was present in only $5.2 \%$ only. The education of the women and socioeconomic status also play an important role. The awareness among rural women was significantly less as compared to urban women.

Conclusions: The awareness about Pap test and cervical cancer vaccine was very low specially in women staying in rural area. So if we really wanted to reduce cervical cancer then we have to increase the awareness among women by media, camps etc.
\end{abstract}

Keywords: Pap smear, Vaccine, Awareness

\section{INTRODUCTION}

Cervical cancer is very common in developing countries. India accounts for $1 / 5^{\text {th }}$ of the burden of cervical cancer. ${ }^{1}$ According to $\mathrm{WHO}^{2} 80 \%$ deaths from cervical cancer were from developing countries. In the developed countries because of screening the incidence of cervical cancer has reduced. Pap smear test is very simple and cost effective test for cervical cancer screening. Pap smear screening has sensitivity of $50-75 \%$ and specificity of $98-99 \%$.

But in developing country like India because of illiteracy and poverty awareness is very low. Few states of India like Uttar Pradesh, Bihar and Madhya Pradesh are far less developed than rest of country. Study was conducted in Eastern part of Uttar Pradesh where poverty and illiteracy is very high. Most of the patient in our tertiary hospital report in advance stage of cervical cancer. This can be prevented by screening and diagnosing early. The aim of this study was to know how much awareness about Pap test and cervical cancer vaccine among patients attending gynaecology OPD and ward at a tertiary care hospital.

\section{METHODS}

A prestructured questionnaire was filled by asking from the patients. This study was conducted in SSH hospital of institute of medical sciences BHU Varanasi, Uttar 
Pradesh India. Total 1500 patients attending gynaecology OPD and inpatients and the female attendants were also enrolled. This study was done for one year.

We observed how many patients are aware of Pap test and cervical cancer vaccine. We also recorded the education status and socioeconomic status of patients. It is also noted whether the patients belong to rural area or urban area.

\section{RESULTS}

Total 1500 patients observed over a period of one year.
The overall awareness among patients about Pap test was only $12.06 \%$ (Table 1). Out of 1500 patients 640 belonged to urban area and 860 belonged to rural area. The awareness about Pap test among rural women was only $3.95 \%$ as shown in Table 2 .

The socioeconomic status and education level also plays an important role. As we can see in Table 3 the awareness about Pap test among graduate women was $21.66 \%$ while among illiterate was only $3.23 \%$. The women with yearly income $>2$ lakh were more aware than with income less than one lakh/year as shown in (Table 4).

Table 1: The awareness present $(n=1500)$.

\begin{tabular}{|l|llllll|}
\hline & $\begin{array}{l}\text { Pap } \\
\text { test }\end{array}$ & $\%$ & Vaccine & $\%$ & $\begin{array}{l}\text { Pap }+ \\
\text { vaccine }\end{array}$ & $\%$ \\
\hline $\begin{array}{l}\text { Awareness } \\
\text { present }\end{array}$ & 181 & $12.06 \%$ & 92 & $6.13 \%$ & 79 & $5.2 \%$ \\
\hline
\end{tabular}

Table 2: The awareness present in urban/rural area.

\begin{tabular}{|lllllll|} 
Urban/rural & $\begin{array}{l}\text { Pap } \\
\text { test }\end{array}$ & Percentage & $\begin{array}{l}\text { Cervical } \\
\text { cancer } \\
\text { vaccine }\end{array}$ & $\%$ & $\begin{array}{l}\text { Pap }+ \\
\text { vaccine }\end{array}$ & $\%$ \\
\hline Urban (640) & 147 & $22.96 \%$ & 83 & $12.96 \%$ & 70 & $10.93 \%$ \\
\hline Rural (860) & 34 & $3.95 \%$ & 9 & $1.04 \%$ & 9 & $1.04 \%$ \\
\hline Total (1500) & $(181)$ & $12.06 \%$ & $(92)$ & $6.13 \%$ & $(79)$ & $5.2 \%$ \\
\hline
\end{tabular}

Table 3: Education status.

\begin{tabular}{|lllllll|} 
& \multicolumn{2}{l}{$\begin{array}{l}\text { PAP test } \\
\text { awareness }\end{array}$} & \multicolumn{2}{l}{$\begin{array}{l}\text { Vaccine } \\
\text { awareness }\end{array}$} & \multicolumn{2}{l|}{$\begin{array}{l}\text { Pap + vaccine } \\
\text { awareness }\end{array}$} \\
& No. & $\%$ & No. & $\%$ & No. & \% \\
\hline Illiterate (340) & 11 & $3.23 \%$ & 3 & $0.88 \%$ & 1 & $0.29 \%$ \\
\hline Matric (560) & 40 & $7.14 \%$ & 23 & $4.10 \%$ & 30 & $5.35 \%$ \\
\hline Graduation (600) & 130 & $21.66 \%$ & 66 & $11 \%$ & 48 & $8 \%$ \\
\hline Total (1500) & 181 & & 92 & & 79 & \\
\hline
\end{tabular}

Table 4: Socioeconomic status.

\begin{tabular}{|lllllll|}
\hline Yearly income & PAP & $\%$ & Vaccine & $\%$ & Both & $\%$ \\
\hline$<100000(600)$ & 15 & $2.5 \%$ & 2 & $0.33 \%$ & 1 & $0.166 \%$ \\
\hline $10000-200000(730)$ & 76 & $10.41 \%$ & 40 & $5.47 \%$ & 40 & $5.47 \%$ \\
\hline$>200000(170)$ & 90 & $52.94 \%$ & 50 & $29.41 \%$ & 38 & $22.35 \%$ \\
\hline Total & 181 & & 92 & & 79 & \\
\hline
\end{tabular}

\section{DISCUSSION}

Inspite of high incidence of cervical cancer in India there are no proper screening programme for cervical cancer. Today also maximum patient report with advance stage of cervical cancer. In our study we had shown that awareness about cervical cancer screening by Pap test is very low specially among rural women. It has been seen from the population based cancer registers that cervical cancer is on decline but rates are still too high mainly in rural areas, and the absolute number has increased due to population growth. ${ }^{3}$

Indian study done by Singh E et al. among nursing staff had shown that $96 \%$ respondents had heard about Pap smear. ${ }^{4}$ 
A study from Turkey was done by Ertem ${ }^{5}$ shows that all respondents had heard about Pap smear. But in our study only $12.06 \%$ patient had heard about Pap test and only $6.03 \%$ women had heard about cervical cancer vaccine. A study done in Karnataka (India) by Montogomery et al. ${ }^{6}$ had shown that $36 \%$ women herd of HPV and only $5 \%$ women reported to have Pap smear. We should not lose any opportunity to screen women whenever they visit hospital for any problem.

In our study we had seen that education status and socioeconomic status also plays an important role. Rural women were less aware as compared to urban women.

\section{CONCLUSION}

The awareness of cervical cancer screening, vaccine for cervical cancer prevention is very low in this part of India specially in poor, illiterate women living in rural areas. To prevent cervical cancer we should make women aware with the help of mass media, health camps. We should also educate these women about how simple and effective is the Pap test. We should also teach paramedical staff about the importance of Pap test.

Funding: No funding sources Conflict of interest: None declared

Ethical approval: The study was approved by the institutional ethics committee

\section{REFERENCES}

1. Desai M. An assessment of community based cancer screening program among Indian women using the Anganwadi workers. J Obstet Gynecol India. 2004;54:483-7.

2. WHO. Cervical screening in developing countries. In: WHO, eds. Report of a WHO Consultation. Geneva: WHO; 2002.

3. Sankaranaryanan R, Budukh AM, Rajkumar R. Effective screening programmes for cervical cancer in low-and-middle-income developing countries. Bull World Health Organ. 2001;79:954-62.

4. Singh E, Seth S, Rani V, Srivastava DK. Awareness of cervical cancer screening among nursing staff in a tertiary institution of rural India. J Gynecol Oncol. 2012 Jul;23(3):141-6.

5. Ertem G. Awareness of cervical cancer risk factors and screening behavior among nurses in a rural region of Turkey. Asian Pac J Cancer Prev. 2009;10:735-8.

6. Montgomery MP, Dune T, Shetty PK, Shetty AK. Knowledge and acceptance of human papilloma virus vaccination and cervical cancer screening among women in Karnataka, India. J Cancer Educ. 2015 Mar;30(1):130-7.

DOI: $10.5455 / 2320-1770$. ijrcog20150430

Cite this article as: Rani A, Singh K, Thapa S. A survey of awareness of Pap smear and cervical cancer vaccine among women at tertiary care centre in Eastern Uttar Pradesh India. Int J Reprod Contracept Obstet Gynecol 2015;4:439-41. 